\title{
CXXXVI. STUDIES IN FAT METABOLISM IN THE FOWL.
}

\section{THE COMPOSITION OF THE EGG FAT AND DEPOT FAT OF THE FOWL AS AFFECTED BY THE INGESTION OF LARGE AMOUNTS OF DIFFERENT FATS.}

\author{
BY ETHEL MARGARET CRUICKSHANK. \\ Poultry Nutrition Section, Animal Nutrition Institute, \\ School of Agriculture, Cambridge.
}

(Received April 20th, 1934.)

ThE study of the formation and utilisation of fat in the fowl is of fundamental interest, since our knowledge of these processes in the bird is very meagre, investigations of fat metabolism having been so far carried out almost exclusively on mammals. With a view to eliciting information along these lines it was decided to investigate two problems which presented themselves as being of primary importance to the poultry industry. (1) The approximate composition of the mixed fatty acids of the normal egg and the extent to which this may be modified by the inclusion of fat in the ration. (2) The influence of ingested fat on the composition of the depot fat. The latter investigation is of a preliminary nature.

In the following paper the two problems outlined will be dealt with in separate sections.

\section{SECTION I.}

EFfect of ingested fat on the composition of THE EGg Fat.

The data available for the egg fat concern chiefly the neutral fats or the phosphatides and not the mixed fatty acids of the entire yolk. The ether extract of the fresh yolk is about $30-32 \%$, a figure that appears to remain relatively constant, but variable results have been obtained for the phosphatide content, e.g. Mangold [1931], $4 \%$; McCollum et al. [1912], 9.4\%; Manasse [1906], 9-10\%; Serono and Palozzi [1911], 11-12\%.

The discrepancy between these results is probably due to the fact that no satisfactory method for estimating the amount of phosphatide present has yet been evolved, but it is possible also that the phosphatide content may be dependent on certain variable factors.

Many workers have investigated the composition of egg-lecithin with regard to its different components. References to this are given by MacLean [1918] and Needham [1931]. Cousin [1903], working chiefly on commercial samples of egg-lecithin, estimated the proportions of the different fatty acids present as follows: palmitic, $28.5 \%$; stearic, $14 \cdot 2 \%$; oleic, $33 \%$; linoleic, $24 \%$. Levene and Rolf [1922] and Hatakeyama [1930] both recorded the presence of arachidonic 
acid, and stated that linoleic acid was present only in small amount. The former found that, in contrast to liver-lecithin, egg-lecithin contained only a small proportion of highly unsaturated acids. Sueyoshi and Furukubo [1931], working with lecithin carefully purified from fat and kephalin, found that the saturated acids consisted mainly of isopalmitic acid, with only small amounts of palmitic and stearic acids. The proportions of the unsaturated acids present, calculated from their bromination products, were as follows: oleic, $73.2 \%$; clupanodonic, $5 \cdot 1 \%$; linoleic, $2 \cdot 1 \%$.

The results obtained for the composition of the neutral fat by the earlier workers [Liebermann, 1888; Kitt, 1897; Serono and Palozzi, 1911], present wide variations and are subject to criticism on account of the technique employed. The only detailed quantitative analysis of the egg fat available is that of Grossfeld [1933], who examined the mixed fatty acids obtained from the egg by the following method. Egg-yolks were treated with warm hydrochloric acid and extracted with light petroleum. The solution was freed from acid and water and the oil obtained by evaporation. It contained $5 \cdot 1 \%$ of unsaponifiable material and $90.7 \%$ of mixed fatty acids, of the following composition: higher saturated fatty acids (permanganate method) $34.6 \%$; solid saturated fatty acids (lead salt-alcohol method) $32.4 \%$; stearic acid $2.2 \%$; palmitic acid $32.4 \%$; oleic acid 44.2\%; linoleic acid $18.0 \%$; linolenic acid (Kaufmann) $3 \cdot 2 \%$. Butyric and $n$-octanoic acids were absent.

Various investigators have ascertained that the composition of the egg fat is affected by feeding. Henriques and Hansen [1903] found that on a carbohydrate diet the iodine value of the neutral fat averaged 78.8 . With linseed feeding it rose to 97 and with hempseed to 119-123. Although the neutral fat was affected by the feeding, the fatty acids of the lecithins remained unchanged. This finding was not confirmed by McCollum et al. [1912] who found that the iodine value of the neutral fats varied from 52 on an approximately lipoid-free diet to 64 on an ordinary ration, while the iodine value of the lecithins on the former was 35 , and on the latter 63 . Similar results were obtained by Terroine and Belin [1927].

It thus appears that there is comparatively little reliable information available as to the composition of the egg fat, and though it has been ascertained that it may be affected by the nutrition of the fowl, yet we have no knowledge with regard to the changes which take place in the proportions of the component fatty acids.

\section{EXPERIMENTAL.}

In the experiments to be described, Light Sussex hens were kept under ordinary commercial conditions with access to free range. The control ration, which was the ordinary stock ration used on the farm, consisted of bran, maize, sharps and Sussex ground oats, supplemented by $7 \%$ extracted soya bean meal, $7 \%$ fish meal, and $3 \%$ mineral mixture. The experimental groups (with one exception) received the control ration with the addition of high percentages of fats of varying composition.

The effect of ingested fat was studied $(a)$ on successive eggs of individual hens, alteration in iodine value being taken as indication of a change in composition, and $(b)$ on composite samples of eggs taken from groups of birds receiving different types of fat in the ration.

Under $(a)$ the effects of a relatively saturated fat, viz. mutton fat (incorporated in the control ration at a $28 \%$ level) and a highly unsaturated oil, viz. hemp oil (fed in the form of hempseed alone) were investigated. The birds were trap- 
nested, and the individual eggs collected. Each yolk was separated from the white as completely as possible and gradually diluted with distilled water, $10 \mathrm{ml}$. of alcohol and $5 \mathrm{ml}$. of $40 \% \mathrm{KOH}$ were added and the whole was made up to $200 \mathrm{ml}$. Aliquot portions of this were saponified with a further addition of alcoholic potash for $1 \frac{1}{2}$ hours in an evacuated pressure-flask on a steam-bath. The saponified solution was then treated according to the method described by Mottram [1910] for the estimation of the fatty acids of liver tissue. The mixed fatty acids were dried to constant weight in an oven through which a current of $\mathrm{CO}_{2}$ was passing, and the iodine values were determined by Wijs's method. The changes occurring in the egg fat as shown by the iodine values are shown graphically in Fig. 1.

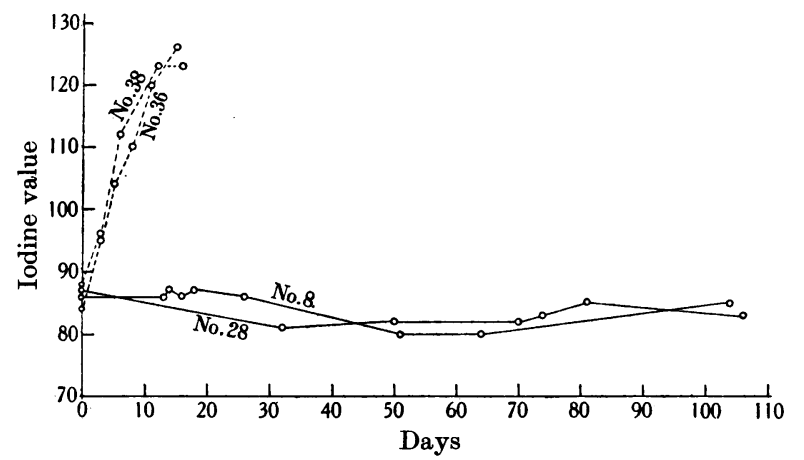

Fig. 1. Effect of ingestion of hemp oil and mutton fat on the mixed fatty acids of egg-yolk. ---- Hemp oil (I.v. = 164); - Mutton fat (I.v.=45).

In section $(b)$ the experimental rations were as follows:

(1) Fish meal-free mash ।

(2) Control mash

(3) , $\quad+28 \%$ palm kernel oil.

(4) $\quad, \quad+28 \%$ palm oil.

(5) $\quad, \quad+28 \%$ mutton fat.

(6) $\quad$, $\quad+28 \%$ linseed oil.

(7) $\quad, \quad+28 \%$ hemp oil.

(8) Hempseed alone.

The fish meal-free ration (which contained degermed maize, bran, whole yeast, rice, alfalfa and mineral mixture, with $7 \%$ extracted soya bean meal) was fed in addition to the control mash, since it was thought that the fish meal contained in the latter might possibly influence to some extent the composition of the mixed fatty acids of the egg. The ether extract of the former was only $2.3 \%$ as compared with $3.8 \%$ in the control ration, as the constituents were selected for their low fat content. Analyses of the normal rations and of hempseed are given in Table I.

Table I. Average composition of rations.

$\begin{array}{lcccccc} & \begin{array}{c}\text { Moisture } \\ \%\end{array} & \begin{array}{c}\text { Ether } \\ \text { extract }\end{array} & \begin{array}{c}\text { Protein } \\ \%\end{array} & \begin{array}{c}\text { Carbo- } \\ \text { hydrate } \\ \%\end{array} & \begin{array}{c}\text { Fibre } \\ \%\end{array} & \begin{array}{c}\text { Ash } \\ \%\end{array} \\ \text { Control } & 12 \cdot 5 & 3 \cdot 8 & 14 \cdot 1 & 57 \cdot 9 & 6 \cdot 6 & 5 \cdot 1 \\ \text { Fish meal-free } & 10 \cdot 9 & 2 \cdot 3 & 13 \cdot 7 & 67 \cdot 8 & 1 \cdot 3 & 4 \cdot 0 \\ \text { Hempseed } & 8 \cdot 5 & 29 \cdot 5 & 24 \cdot 3 & 15 \cdot 0 & 17 \cdot 9 & 6 \cdot 7 \\ \text { Biochem. } 1934 \text { xxviII } & & & & & & 62\end{array}$


Rations 3-8 represent wide differences in the composition of the ingested oils, those in groups 3-5 having a solid acid content ranging from $80 \%$ in the palm kernel oil to $46 \%$ in the palm oil, with unsaturated acids consisting mainly of oleic acid, while in 6,7 and 8 the percentage of solid acids varies from 6 to $9 \%$, and the unsaturated acids contain a large proportion of linoleic and a considerable amount of linolenic acid. Analyses of the oils are given in Table II.

Table II.

\begin{tabular}{|c|c|c|c|c|c|}
\hline \multicolumn{6}{|c|}{ Composition of oils. } \\
\hline & & Hemp oil & Linseed oil & Palm oil & Mutton fat \\
\hline Oil & $\begin{array}{l}\text { I.v. } \\
\text { Sap. no. } \\
\text { Mol. wt. } \\
\text { CNS value }\end{array}$ & $\begin{array}{r}163 \cdot 7 \\
190 \cdot 4 \\
294 \cdot 7 \\
93 \cdot 1\end{array}$ & $\begin{array}{l}180 \cdot 6 \\
191 \cdot 7 \\
292 \cdot 6 \\
112 \cdot 8\end{array}$ & $\begin{array}{c}53 \cdot 1 \\
196 \cdot 0 \\
286 \cdot 2 \\
-\end{array}$ & $\begin{array}{r}44 \cdot 5 \\
196 \cdot 3 \\
285 \cdot 8 \\
-\end{array}$ \\
\hline Mixed acids & $\begin{array}{l}\text { r.v. } \\
\text { Mol. wt. } \\
\text { \% solid acids }\end{array}$ & $\begin{array}{r}172 \cdot 9 \\
283 \cdot 0 \\
6 \cdot 1\end{array}$ & $\begin{array}{c}191 \cdot 54 \\
282 \cdot 2 \\
9 \cdot 2\end{array}$ & $\begin{array}{r}55 \cdot 0 \\
273 \cdot 8 \\
46 \cdot 3\end{array}$ & $\begin{array}{r}46 \cdot 1 \\
277 \cdot 0 \\
51 \cdot 0\end{array}$ \\
\hline Liquid acids & $\begin{array}{l}\text { I.v. } \\
\text { Mol. wt. } \\
\text { CNS value }\end{array}$ & $\begin{array}{l}183 \cdot 0 \\
280 \cdot 3 \\
104 \cdot 7\end{array}$ & $\begin{array}{l}206 \cdot 5 \\
282 \cdot 0 \\
131 \cdot 4\end{array}$ & $\begin{array}{c}103 \cdot 8 \\
283 \cdot 4 \\
-\end{array}$ & $\begin{array}{r}89 \cdot 2 \\
276 \cdot 0 \\
-\end{array}$ \\
\hline \multicolumn{6}{|c|}{ Percentage composition of mixed fatty acids. } \\
\hline & $\begin{array}{l}\text { Solid acids } \\
\text { Oleic acid } \\
\text { Linoleic acid } \\
\text { Linolenic acid }\end{array}$ & $\begin{array}{r}6 \cdot 1 \\
11 \cdot 9 \\
67 \cdot 2 \\
14 \cdot 8\end{array}$ & $\begin{array}{c}9 \cdot 2 \\
11 \cdot 41 \\
38 \cdot 98 \\
40 \cdot 41\end{array}$ & $\begin{array}{r}46 \cdot 3 \\
46 \cdot 4 \\
7 \cdot 3 \\
-\end{array}$ & $\begin{array}{r}51 \cdot 0 \\
46 \cdot 8 \\
2 \cdot 2 \\
-\end{array}$ \\
\hline
\end{tabular}

Palm kernel oil was not examined, but according to Collin and Hilditch [1928] its component fatty acids are: myristic, lauric and lower saturated acids, $70.7 \%$; palmitic, $8.8 \%$; stearic, $1.3 \%$; oleic, $18 \%$; with only a trace of linoleic acid.

Samples consisting of 10-12 eggs were collected from the different groups after at least 6-8 weeks from the commencement of feeding the experimental rations. The yolks were separated from the whites and ground up with anhydrous sodium sulphate. This material was then extracted in a Bolton and Revis extractor for prolonged periods with anhydrous ether, the solvent being frequently changed, until on evaporation no residue remained. The egg oil thus obtained, which was viscid and orange-coloured, was dried in vacuo at $100^{\circ}$ and when not analysed immediately was put into small ground stoppered bottles and stored in the dark at $-20^{\circ}$.

No attempt was made to separate the neutral fats from the phosphatides, owing to the great difficulty of obtaining either of them in a pure state without admixture with the other. Since the oil obtained by the method just described yielded mixed acids the iodine value of which was only slightly lower than that of the mixed acids obtained by the Mottram saponification method, it was considered that all except very small amounts of the total fatty acids derived from both the neutral fats and the phosphatides had been extracted, and it is probable therefore that the analyses given are representative of the total fatty acids of the egg-yolk. This view is supported by the fact that our results for normal eggs agree well with those of Grossfeld [1933], who, by his method of heating the yolk with hydrochloric acid, undoubtedly obtained the phosphatidefatty acids as well as the fatty acids of the neutral fat in his mixed acids.

The oil obtained by the extraction method was saponified, the unsaponifiable matter removed, the mixed fatty acids precipitated with hydrochloric acid, taken up in light petroleum and dried in vacuo at $100^{\circ}$. 
Determinations were made of the iodine value and molecular weight of the mixed acids. The solid and liquid acids were separated by crystallisation of the lead salts from $95 \%$ alcohol [Twitchell, 1921], using the procedure of Hilditch and Priestman [1931]. The iodine value of the solid acids was estimated and the percentage of solid acids corrected for any oleic acid present.

The solid acids always contained traces of a brownish non-fatty material, which did not dissolve during the second precipitation of the lead salts. The molecular weights therefore are probably slightly too high.

The alcoholic solution of the liquid acids was diluted to twice its volume, the liquid acids separated with dilute acetic acid and taken up in light petroleum. The ethereal solution was repeatedly washed till free from acid, the ether evaporated off and the acids dried in vacuo at $100^{\circ}$.

The iodine value, molecular weight and thiocyanogen value (CNS value) of the liquid acids were determined. The percentage of hexabromides was estimated in a few cases, but did not prove satisfactory, and it was decided to substitute the thiocyanogen value as a means of estimating the linolenic acid, information having been obtained that this method gave higher and more accurate results [Griffiths and Hilditch, 1934]. Determinations were carried out, with careful attention to the absolute dryness of all reagents and apparatus employed, as recommended by Kaufmann and Keller [1929].

Oleic and linoleic acids were calculated from the iodine value of the mixed acids after allowance had been made for the solid acids and linolenic acid present. It was assumed that acids more unsaturated than linolenic acid were absent, though this was probably not strictly true.

Results of the analyses of the mixed fatty acids of the egg fat are given in Table III.

Table III.

Composition of mixed fatty acids of egg-yolk.

\begin{tabular}{|c|c|c|c|c|c|c|c|c|c|}
\hline & & $\begin{array}{c}\text { Control } \\
\text { mash }\end{array}$ & $\begin{array}{c}\text { Fish } \\
\text { meal-free } \\
\text { mash }\end{array}$ & $\begin{array}{c}\text { Mash }+ \\
\text { palm } \\
\text { kernel oil }\end{array}$ & 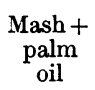 & $\underset{\text { matton }}{\text { Mash }+}$ & $\begin{array}{c}\text { Mash }+ \\
\text { linseed } \\
\text { oil }\end{array}$ & $\underset{\text { oil }}{\text { Mash }+}$ & $\begin{array}{l}\text { Hempseed } \\
\text { alone }\end{array}$ \\
\hline $\begin{array}{r}\text { Mixed } \\
\text { acids }\end{array}$ & $\begin{array}{l}\text { I.v. } \\
\text { Mol. wt. }\end{array}$ & $\begin{array}{r}84 \cdot 4 \\
280 \cdot 5\end{array}$ & $\begin{array}{r}80 \cdot 0 \\
283 \cdot 0\end{array}$ & $\begin{array}{r}80 \cdot 5 \\
280 \cdot 3\end{array}$ & $\begin{array}{r}85 \cdot 9 \\
281 \cdot 4\end{array}$ & $\begin{array}{r}84 \cdot 0 \\
284 \cdot 0\end{array}$ & $\begin{array}{l}123 \cdot 1 \\
281 \cdot 8\end{array}$ & $\begin{array}{l}115 \cdot 7 \\
282 \cdot 1\end{array}$ & $\begin{array}{l}127 \cdot 2 \\
280 \cdot 6\end{array}$ \\
\hline $\begin{array}{l}\text { Solid } \\
\text { acids }\end{array}$ & $\begin{array}{l}\% \\
\text { Mol. wt. }\end{array}$ & $\begin{array}{r}31 \cdot 4 \\
263 \cdot 5\end{array}$ & $\begin{array}{r}31 \cdot 2 \\
264 \cdot 0\end{array}$ & $\begin{array}{r}30 \cdot 3 \\
266 \cdot 4\end{array}$ & $\begin{array}{r}27 \cdot 8 \\
265 \cdot 5\end{array}$ & $\begin{array}{r}29 \cdot 5 \\
268 \cdot 0\end{array}$ & $\begin{array}{r}23 \cdot 9 \\
265 \cdot 7\end{array}$ & $\begin{array}{r}24 \cdot 3 \\
267 \cdot 4\end{array}$ & $\begin{array}{r}21 \cdot 4 \\
266 \cdot 0\end{array}$ \\
\hline $\begin{array}{l}\text { Liquid } \\
\text { acids }\end{array}$ & $\begin{array}{l}\text { I.v. } \\
\text { Mol. wt. } \\
\text { CNS value }\end{array}$ & $\begin{array}{r}121 \cdot 2 \\
278 \cdot 2 \\
94 \cdot 0\end{array}$ & $\begin{array}{r}115 \cdot 9 \\
284 \cdot 0 \\
93 \cdot 3\end{array}$ & $\begin{array}{r}115 \cdot 0 \\
278 \cdot 8 \\
92 \cdot 3\end{array}$ & $\begin{array}{r}120 \cdot 0 \\
280 \cdot 0 \\
90 \cdot 8\end{array}$ & $\begin{array}{r}117 \cdot 7 \\
283 \cdot 3 \\
93 \cdot 7\end{array}$ & $\begin{array}{l}161 \cdot 3 \\
283 \cdot 4 \\
111 \cdot 2\end{array}$ & $\begin{array}{r}156 \cdot 3 \\
281 \cdot 1 \\
96 \cdot 4\end{array}$ & $\begin{array}{l}162 \cdot 8 \\
278 \cdot 9 \\
101 \cdot 8\end{array}$ \\
\hline \multicolumn{10}{|c|}{ Percentage composition of mixed fatty acids. } \\
\hline & $\begin{array}{l}\text { Solid acids } \\
\text { Oleic acid } \\
\text { Linoleic acid } \\
\text { Linolenic acid }\end{array}$ & $\begin{array}{r}31 \cdot 4 \\
46 \cdot 7 \\
19 \cdot 0 \\
2 \cdot 9\end{array}$ & $\begin{array}{r}31 \cdot 2 \\
51 \cdot 4 \\
15 \cdot 0 \\
2 \cdot 4\end{array}$ & $\begin{array}{r}30 \cdot 3 \\
51 \cdot 9 \\
16 \cdot 1 \\
1 \cdot 7\end{array}$ & $\begin{array}{r}27 \cdot 8 \\
49 \cdot 8 \\
21 \cdot 7 \\
0 \cdot 7\end{array}$ & $\begin{array}{r}29 \cdot 5 \\
50 \cdot 8 \\
16.9 \\
2.8\end{array}$ & $\begin{array}{l}23 \cdot 9 \\
33 \cdot 8 \\
24 \cdot 9 \\
17 \cdot 4\end{array}$ & $\begin{array}{r}24 \cdot 3 \\
28 \cdot 8 \\
41 \cdot 7 \\
5 \cdot 2\end{array}$ & $\begin{array}{l}21 \cdot 4 \\
26 \cdot 7 \\
41 \cdot 9 \\
10 \cdot 0\end{array}$ \\
\hline
\end{tabular}

\section{Discussion.}

No effect on the flavour of the egg was observed during the feeding of the experimental rations, except in the case of linseed oil, which produced an unpleasant taste in the soft-boiled egg.

The results obtained on successive eggs of individual hens show that on the hempseed ration the mixed fatty acids became steadily more unsaturated, the normal iodine value of 84-88 being increased to 123-126 at the end of 16 days, and there remaining constant, showing that by this time all the layers of yolk 
(which are laid down concentrically) had been deposited under the influence of the hempseed diet. The period required for reaching the maximum iodine value is a measure of the period required for the growth of the ovum. This is not necessarily a constant, but will differ in different individuals, or even in the same individual at different seasons, according to the rate of production.

Compared with hempseed, mutton fat had little effect on the iodine value of the mixed acids. A slightly lower value was obtained from the 7 th to the 10th week after the commencement of the period, but towards the end it returned to the normal.

It appears therefore that while unsaturated oils given in the form of a diet such as hempseed readily affect the composition of the yolk fat, as indicated by the change in iodine value, the ingestion of a hard fat, viz. mutton fat, in conjunction with a cereal ration, does not significantly affect it, even after prolonged feeding.

Reference to Table III shows that on a cereal diet with a protein supplement, the degree of saturation of the mixed acids of the egg is similar to that of the mixed acids of the body fat on a normal ration. Solid acids constitute about $31 \%$, and according to the molecular weight $(263 \cdot 7)$ appear to consist mainly of palmitic acid (molecular weight 256).

Oleic acid is the main constituent of the liquid fraction, with smaller amounts of linoleic and 2-3\% of linolenic acid, as determined by the thiocyanogen value. The percentages of linoleic (15-19\%) and of oleic acid (47-51\%) are of the same order as those found by Grossfeld [1931] in hen depot fat. The composition of the mixed fatty acids from the control and fish meal-free eggs is very similar to that recorded by Grossfeld [1933] for commercial eggs of Danish origin.

Since the fish meal-free ration contained only $2-3 \%$ of ether extract, it is evident that a considerable proportion of the normal egg fat must be derived by synthesis from the non-fatty constituents of the food rather than by direct assimilation of fat. It cannot be definitely stated whether synthesis of linolenic acid from carbohydrate takes place or not, since both the control and fish mealfree rations contained soya bean meal, which, even when solvent-extracted, may contain traces of this acid.

The addition of palm kernel oil to the ration produced a fatty acid mixture of the same composition as that of the fish meal-free eggs. No lowering of the molecular weight of the mixed acids or of the iodine value of the liquid acids was observed, as would have been the case had appreciable amounts of the lower saturated acids been deposited.

The ingestion of palm oil and mutton fat did not affect the composition to any significant extent, though in the former case the percentage of linolenic and of solid acids was slightly reduced, and that of the linoleic acid slightly increased.

With the feeding of unsaturated oils a marked increase in the degree of unsaturation took place, accompanied by a decrease in the percentage of solid acids, a marked decrease in oleic acid and an increase in both linoleic and linolenic acids.

The iodine value of the mixed acids was highest, and the percentage of solid acids lowest, on the hempseed diet, i.e. where the ration fed, though rich in unsaturated fatty acids and protein, was relatively deficient in carbohydrate. When the hemp oil was fed in conjunction with a carbohydrate-rich ration, the degree of unsaturation was reduced and the percentage of solid acids slightly raised, as compared with the hempseed diet. The mash plus linseed oil produced a greater degree of unsaturation in the mixed acids than the mash plus hemp oil, 
in accordance with the iodine values of the respective oils. The percentage of solid acids was the same in both cases.

The percentage of linoleic acid appears to be related to some extent to that of the ingested oils. The linoleic acid content of the mixed acids of the oils, and of the mixed acids of the eggs produced on the rations containing them, are as follows: hemp oil, $67 \%$; hempseed and hemp oil eggs, $42 \%$; linseed oil, $39 \%$; linseed eggs, $25 \%$; mutton fat and palm oil, 2-7\%; mutton fat and palm oil eggs, 17-22\%. Even when no added linoleic acid is present in the diet the linoleic content of the egg fatty acids will be approximately 15$19 \%$.

The linolenic acid content also tends to run parallel with that of the ingested oils, the largest amount being found when linseed oil is fed, the percentage here being over five times that found in the normal egg. Hempseed fed alone raised the percentage of linolenic acid in the mixed acids to three times that of the normal egg. In this case the linolenic acid content of the liquid acids, viz. $12.7 \%$, approximates to that present in the oil itself.

When the diet contained ample carbohydrate in addition to the hemp oil, however, the linolenic acid was reduced by $50 \%$. To what extent the linolenic acid content might have been raised on linseed alone could not be determined, as, owing to its unpalatability, fowls can rarely be induced to eat more than small amounts of the seed.

From these results it appears that the hen, even when abundant carbohydrate is present for the synthesis of normal fat, will utilise ingested fatty acids for direct deposition in the egg fat. When the ration containing the unsaturated fatty acids is deficient in carbohydrate, a greater proportion of the acids will be deposited. On the other hand, in spite of the ingestion of large amounts of saturated acids in the presence of ample carbohydrate, the composition of the mixed fatty acids of the egg tends to remain similar to that produced on a cereal plus protein ration containing $2-4 \%$ of ether extract.

It seems possible that in the synthesis of egg fat, the hen exercises a selective influence, and there may be a degree of saturation of the fat which cannot be increased by the ingestion of saturated fatty acids, but which can be reduced to a marked extent by the assimilation of unsaturated acids.

Since the fat of the egg-yolk serves as a source of energy for the developing embryo, the fact that its composition can be materially influenced by certain nutritional factors may be of considerable significance in connection with embryonic nutrition, hatchability, etc.

\section{SECTION II.}

\section{EFFECT OF INGESTED FAT ON THE COMPOSITION OF THE DEPOT FAT.}

The dependence of the constitution of the fat reserves on the composition of the diet has been clearly established in the case of the pig, notably by Ellis and co-workers $[1926 ; 1930 ; 1931]$ in their extensive studies on soft pork, and by Bhattacharya and Hilditch [1931], and in the case of the rat by Anderson and Mendel [1928], Eckstein [1929], Reed et al. [1930], Banks et al. [1933] and others. All these investigators have found that dietary fat may exert a marked effect on the composition of the depot fat.

Little attention however has been directed towards the study of fat formation in birds. Quantitative data exist for the composition of goose fat [Bömer and 
Merten, 1922], and for the fat of the hen [Grossfeld, 1931], but the effect of diet on such composition has received little consideration.

Henriques and Hansen [1903] found that the iodine values of the fat of three hens fed on a diet of hempseed were 103, 120 and 135 respectively. Schirmer [1921] records an iodine value of 74.8 for the fat of geese on a diet of maize and olive oil, and 63.2 on maize and mutton fat. In spite of the statement in a report from the Kansas Agricultural Experiment Station [1922] that "none of the short chain fatty acids of the food are deposited in the body fat of the hen, while the unsaturated fatty acids are so deposited" the actual tabulated data show clearly that either saturated or unsaturated fats can be deposited in the fat depots of the hen.

\section{EXPERIMENTAL.}

The birds in this section of the experiment were kept under the conditions of management already described. The same control ration was employed.

The fats investigated, viz. palm kernel oil, mutton fat and hemp oil, provided examples of fats differing considerably in composition from that of the normal body fat. Since the inclusion of small amounts of fat in the ration only slightly affected the normal composition of the body fat in the pig, it was decided to incorporate the palm kernel oil and mutton fat in the control ration at a high level, viz. $28 \%$. In investigating the effect of hemp oil, hempseed was fed as the sole diet, owing to the difficulty of obtaining sufficient quantities of the oil

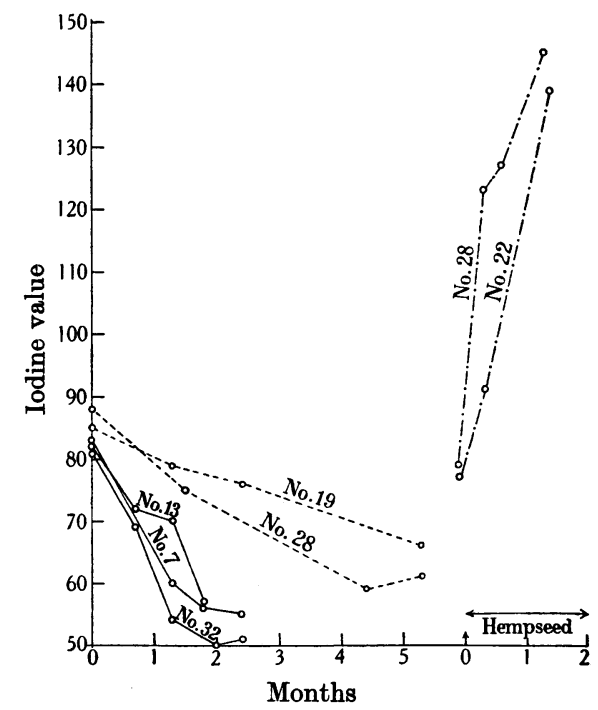

Fig. 2. Effect of ingestion of palm kernel oil, mutton fat and hemp oil on the mixed fatty acids of abdominal fat.

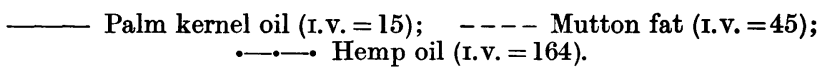

itself. The percentages of fat in these three diets were very similar, since the hempseed contained 28-29\% of ether extract. It was however richer in protein and considerably poorer in carbohydrate than the fat plus mash rations.

The work of Scott [1920] having shown that considerable individual variation in the composition of the body fat occurs in pigs even under the same 
conditions of management and dietary régime, it was decided to study progressive samples of body fat obtained from the same individual during the experimental period.

Samples of fat $(0 \cdot 5-0 \cdot 8 \mathrm{~g}$.) could be readily removed without injury to the bird from the abdominal region, where there is a comparatively large superficial deposit in a well-nourished hen. These were taken while the birds were still on the control ration, and again at intervals during the experimental period. The fat was saponified in evacuated pressure-flasks and the iodine value determined on the mixed fatty acids. The results are shown graphically in Fig. 2.

In pigs and cattle it has also been found that the composition of the fat varies significantly in different areas, therefore samples from the various fat depots were examined to ascertain whether such variation in composition occurs in the fowl. The results are shown in Tables IV and V. As the iodine values of the different areas were very similar, it was assumed that the abdominal layer could safely be taken as representative of the body fat as a whole.

Table IV. Iodine values of mixed fatty acids of fat from different depots.

$\begin{array}{ccccc}\text { No. of hen } & \text { Gizzard } & \text { Neck } & \text { Leg muscle } & \text { Abdominal } \\ 3 & 93 & 92 & 93 & 90 \\ 15 & 79 & 79 & -78 \\ 17 & 64 & 67 & 65 & 65 \\ 25 & 90 & 90 & 90 & 88\end{array}$

Table V. Iodine values of mixed fatty acids of fat from different depots.

\begin{tabular}{|c|c|c|c|c|c|c|c|c|c|c|}
\hline $\begin{array}{l}\text { No. } \\
\text { of } \\
\text { hen }\end{array}$ & Skin & Neck & $\underset{\text { muscle }}{\text { Leg }}$ & $\begin{array}{l}\text { Abdo- } \\
\text { minal }\end{array}$ & Gizzard & Kidney & $\begin{array}{l}\text { Mesen- } \\
\text { teric }\end{array}$ & $\begin{array}{c}\text { Epi- } \\
\text { cardial }\end{array}$ & $\begin{array}{l}\text { Av. } \\
\text { I.v. }\end{array}$ & $\begin{array}{c}\text { Max. } \\
\text { diff. } \\
\text { between } \\
\text { depots }\end{array}$ \\
\hline 5 & $87 \cdot 3$ & $88 \cdot 1$ & $86 \cdot 2$ & $87 \cdot 1$ & $84 \cdot 5$ & $84 \cdot 4$ & $84 \cdot 0$ & $85 \cdot 6$ & $85 \cdot 9$ & $4 \cdot 1$ \\
\hline 8 & $81 \cdot 4$ & 78.0 & - & - & $75 \cdot 6$ & $77 \cdot 7$ & - & - & $78 \cdot 2$ & $5 \cdot 8$ \\
\hline 29 & $92 \cdot 0$ & 89.98 & $88 \cdot 4$ & $88 \cdot 1$ & $89 \cdot 0$ & $87 \cdot 8$ & $88 \cdot 0$ & $90 \cdot 2$ & $89 \cdot 2$ & $4 \cdot 2$ \\
\hline 32 & 85.9 & $81 \cdot 7$ & $81 \cdot 2$ & $80 \cdot 8$ & $79 \cdot 7$ & $81 \cdot 6$ & 80.7 & $85 \cdot 7$ & $82 \cdot 2$ & $6 \cdot 2$ \\
\hline
\end{tabular}

\section{Discussion.}

Composition of different fat depots.

In the hen fat is deposited as a thick abdominal layer and as a layer surrounding the gizzard. Smaller deposits are found in the neck region, chiefly between the clavicles, and also along the ventral muscles of the femur. The last-mentioned two deposits are relatively superficial.

Table IV shows that the iodine values of the fatty acids of the main fat depots are very similar. Since this is in contrast to the findings in pigs and cattle, examination of the smaller depots was made, with the results shown in Table V. The skin fat was obtained by extraction of the skin itself, which contains a certain amount of fat along the tracts of the feather follicles. The gizzard fat was obtained from the dorsal side of the gizzard only, as the fat on the ventral side is more or less continuous with the abdominal layer. The differences in iodine value are slightly greater than in Table IV but are nevertheless much smaller than those recorded for pigs and cattle. In two cases the skin is the most unsaturated layer, in one the epicardial fat is equally high, in the fourth the neck fat is one unit higher. It is evident that the most deepseated layers, viz. kidney, mesenteric and epicardial fat, do not show a decidedly lower iodine value than the subcutaneous fat, as recorded by Henriques and 
Hansen [1901] in cattle, where the iodine value of the skin fat was 52, and that of the mesenteric fat 40 . Even greater differences were found by Bhattacharya and Hilditch [1931] in pigs on a normal ration, where the iodine value ranged from 63 in the outer back fat to 46 in the perinephric fat. The various fat depots of the hen therefore, judged by the iodine values, appear to be of more uniform composition than is the case in certain mammals. That the uniformity extends also to the component fatty acids has been shown by the detailed analyses of Hilditch et al. [1934]. This fact lends support to the suggestion that the temperature of the different areas is not the sole factor in determining the composition of the fat reserves [Dean and Hilditch, 1933].

The variation between individuals in Table IV is due to the fact that the birds were taken from the fat-fed groups at various times. No. 8 (Table V) had also received a ration containing mutton fat for 6 weeks. Nos. 5, 29 and 32, however, which were all on the control ration, show that some individual variation in composition exists, even under identical nutrition and management, as is the case also in pigs [Scott, 1920].

\section{Effect of ingested fat on the composition of the body fat.}

In Fig. 2 individual variation is again evident in the five hens examined at the commencement of the experimental period, while they were still on the control ration, the iodine values ranging from 81 to 88 . A steady change towards a harder fat occurred when rations containing $28 \%$ of mutton fat and of palm kernel oil were fed. Individuals however varied slightly in rate and degree of response to the diets. For example, in the case of No. 19 the mutton fat ration lowered the iodine value from its original level (85) to 66 at the end of about 5 months, while in No. 28 the iodine value fell from 88 to 59 in $4 \frac{1}{2}$ months. After this the iodine value of No. 28 appeared to continue at practically the same level. Three other hens (not shown in the figure) on the mutton fat mash were operated on, and it was evident from observation of the birds that the individual response to the feeding depended in a large measure on the physiological condition of the bird (whether laying, non-laying or broody) and the resulting capacity for food consumption. The iodine value in No. 28, whose food intake was very high, fell lower than in any of the other birds examined.

The birds on the palm kernel oil mash showed a marked response to the ingestion of this oil, the iodine value falling from the original level (81-83) to $51-55$ in a little over 2 months. The more rapid change in this case was probably due to two causes. (1) The iodine value of the palm kernel oil, viz. 15, is much farther removed from that of the body fat than is that of mutton fat, viz. 45, hence the ingestion of equal amounts of the two fats would result in a greater decrease in iodine value in the case of the palm kernel oil feeding. (2) The palm kernel oil mash was obviously much more palatable to the birds than the mutton fat mash, and food consumption was therefore greater.

Four birds in the hempseed group were operated on. In each case a rapid and pronounced change in the direction of increased unsaturation took place. The results for two of the birds are shown in Fig. 2. No. 28 showed the most rapid and most marked response, the iodine value of 79 at the commencement of the period being raised to 145 within 6 weeks. In No. 22 the iodine value rose to 139 , and in the other two birds to 124 and 130 respectively within the same period.

With regard to these data it should be noted that though the fat content of the diet was approximately the same in the three groups, the birds on hemp- 
seed were receiving a ration which was considerably richer in protein but contained only a third of the carbohydrate content of the fat plus mash rations. In consequence, they probably tended to lay down the ingested fat more rapidly than if supplied with a ration containing an adequate amount of carbohydrate from which the normal body fat could be synthesised. The results show clearly, as did the tabulated data of the Kansas Agricultural Experiment Station Report [1922] that the degree of saturation of the mixed fatty acids of the body fat can be either increased or decreased by the ingestion of appropriate fats in the ration.

The record of the variations in the iodine value of the mixed fatty acids of the abdominal fat of No. 28 over the 12-month period during which she was under experiment seems worthy of note (see Table VI).

\section{Table VI. Changes in iodine value of mixed fatty acids} of abdominal fat of No. 28 .

\begin{tabular}{|c|c|c|c|c|c|}
\hline Date & I.v. & & Date & I.v. & \\
\hline - & 88 & Control ration & 10. xii. 31 & 123 & Hempseed ration \\
\hline 1. vi. 31 & - & Mutton fat ration & 17. xii. 31 & 127 & , \\
\hline 14. vii. 31 & 75 & ," & 9. i. 32 & 145 & \\
\hline 8. x. 31 & 59 & , & 16. i. 32 & - & Control ration \\
\hline 10. xi. 31 & 61 & 9 & 28. i. 32 & 139 & 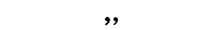 \\
\hline - & $=$ & Control ration & 10. ii. 32 & 137 & , \\
\hline 30. xi. 31 & 79 & - & 3. iii. 32 & 115 & , \\
\hline 1. xii. 31 & - & Hempseed ration & 2. vi. 32 & 90 & , \\
\hline
\end{tabular}

It will be seen that saturation has taken place more slowly than unsaturation, both during the production of a more saturated fat than the normal, and in the production of a normal fat from an abnormally unsaturated one. This does not necessarily mean that the hen tends to select the unsaturated acids more readily than the saturated acids, since various factors may have combined to produce this effect. The palatability of the respective rations, the ratio of fat to carbohydrate present, the degree of divergence of the iodine value of the ingested fat from that of the body fat, the varying appetite and condition of the bird, must all be taken into account.

The rapidity with which the experimental rations have influenced the composition of the body fat is not very surprising in view of the hen's intense physiological activity. In the fowl, the weight of thyroid per kg. of body weight, and also the percentage of iodine in the thyroid are greater than in mammals [Cruickshank, 1929]. A higher metabolic rate therefore results, as shown by the body temperature $\left(104-108^{\circ} \mathrm{F}\right.$. as compared with $101^{\circ} \mathrm{F}$. in the cow, or $103^{\circ} \mathrm{F}$. in the pig). Respiration and heart beat, digestion and absorption are more rapid, while food consumption per unit of body weight is considerably greater. The high metabolic rate is essential in a system of reproduction entailing a rapid transformation of raw materials into food constituents for embryonic use. In a hen laying 250 eggs per annum, this involves an output of $31 \mathrm{lbs}$. of eggs, of which $4 \cdot 1 \mathrm{lbs}$. are protein, $3.3 \mathrm{lbs}$. are fat and $3 \cdot 1 \mathrm{lbs}$. are $\mathrm{CaCO}_{3}$ in the form of shell.

From our results it appears that the selection which the hen exercises with regard to the deposition of ingested fat in the egg does not hold in the case of the body fat, which, so far as can be ascertained by the iodine value, may be markedly influenced by the fatty acids ingested, irrespective of their degree of saturation. It seems possible also that changes in the composition of the fat can be more rapidly induced in the bird than in the mammal, owing to the higher rate of metabolism of the former and the resulting rapid utilisation of food. 


\section{SUMmaRY.}

Effect of ingested fat on the composition of the egg fat. On normal cereal rations containing protein supplements, the mixed fatty acids of the egg fat contained about $31 \%$ solid acids, 47-51 \% oleic acid, 15-19\% linoleic acid and 2-3\% linolenic acid.

While the degree of saturation and the proportion of the component fatty acids could be considerably modified by the ingestion of unsaturated fatty acids, the ingestion of saturated acids had relatively little effect in altering the normal composition of the mixed fatty acids of the egg fat.

Effect of ingested fat on the composition of the depot fat. The iodine values of the mixed fatty acids of the different fat depots in the hen were determined. These indicated that the superficial and internal fat reserves are more uniform in composition than in the case of pigs and cattle.

Observations on individual birds showed that the ingestion of high percentages of saturated fatty acids in the form of palm kernel oil and mutton fat definitely decreased the degree of saturation of the mixed fatty acids of the depot fat, while the ingestion of unsaturated acids in the form of hempseed resulted in a marked and rapid increase in unsaturation.

I am greatly indebted to Mr E. T. Halnan for his interest and encouragement throughout the work. My best thanks are also due to Prof. T. P. Hilditch, whose advice and helpful criticism have been invaluable. The expenses of the investigation have been defrayed by a grant from the Empire Marketing Board.

\section{REFERENCES.}

Anderson and Mendel (1928). J. Biol. Chem. 76, 729.

Banks, Hilditch and Jones (1933). Biochem. J. 27, 1375.

Bhattacharya and Hilditch (1931). Biochem. J. 25, 1954.

Bömer and Merten (1922). Z. Unters. Nahr. Genussm. 43, 101.

Collin and Hilditch (1928). J. Soc. Chem. Ind. 47, 261.

Cousin (1903). Compt. Rend. Soc. Biol. 55, 913.

Cruickshank (1929). Biochem. J. 23, 1044.

Dean and Hilditch (1933). Biochem. J.27, 1950.

Eckstein (1929). J. Biol. Chem. 81, 613.

Ellis and Isbell (1926). J. Biol. Chem. 69, 239.

- and Zeller (1930). J. Biol. Chem. 89, 185.

- Rothwell and Pool (1931). J. Biol. Chem. 92, 385.

Griffiths and Hilditch (1934). J. Soc. Chem. Ind. 53, 75 T.

Grossfeld (1931). Z. Unters. Lebensm. 62, 553.

- (1933). Z. Unters. Lebensm. 65, 311.

Hatakeyama (1930). Z. physiol. Chem. 187, 120.

Henriques and Hansen (1901). Skand. Arch. Physiol. 11, 151. (1903). Skand. Arch. Physiol. 14, 390.

Hilditch, Jones and Rhead (1934). Biochem. J. 28, 768.

— and Priestman (1931). Analyst, 56, 354.

Kansas Agric. Exp. Sta. Biennial Rep. (1922), 17.

Kaufmann and Keller (1929). Z. angew. Chem. 42, 20, 73.

Kitt (1897). Chem. Zentr. 68, 1131.

Levene and Rolf (1922). J. Biol. Chem. 51, 507. 
Liebermann (1888). Pflüger's Arch. 43, 71.

MacLean(1918). Lecithin and allied substances. (Longmans, Green and Co., London.)

McCollum, Halpin and Drescher (1912). J. Biol. Chem. 13, 219.

Manasse (1906). Biochem. Z. 1, 246.

Mangold (1931). Arch. Geflügelk. 5, 286.

Mottram (1910). J. Physiol. 40, 122.

Needham (1931). Chemical embryology. (Cambridge Univ. Press.)

Reed, Yamaguchi, Anderson and Mendel (1930). J. Biol. Chem. 87, 147.

Scott (1920). Florida Agric. Exp. Sta. Bull. No. 157.

Schirmer (1921). Arch. exp. Path. Pharm. 89, 263.

Serono and Palozzi (1911). Chem. Zentr. 82, 772.

Sueyoshi and Furukubo (1931). J. Biochem. 13, 155, 177.

Terroine and Belin (1927). Bull. Soc. Chim. Biol. 9, 12.

Twitchell (1921). J. Ind. Eng. Chem. 13, 806. 